\title{
TO CULTIVATE PIETY, LEARNING, AND LIBERTY: THE COLLEGE OF NEW JERSEY AND QUEEN'S COLLEGE, \\ 1746-1794
}

\section{BY THOMASJ. FRUSCIANO}

\section{Mr. Frusciano is University Archivist, Special Collections and University Archives, Rutgers University Libraries}

On October 29, 1793, in a meeting of the board, the Trustees of Queen's College convened in New Brunswick to discuss a plan to merge with the College of New Jersey at Princeton. Queen's College was in a precarious state. In 1790 following the death of its first president, the Reverend Jacob R. Hardenbergh, the college was unable to secure a successor. Its finances were meager and any support from the General Synod of the Dutch Reformed Church was dependent upon the college's ability to attract a leader who would also serve as Professor of Divinity. The logical choice was the Reverend John Henry Livingston, architect of the 1773 Articles of Union, which united the two factions in the Dutch Reformed Church. When Livingston declined, the trustees found themselves hard pressed to continue instruction, and were forced to explore ways of keeping the doors of their fledgling institution open.

A "Plan of Union," formulated by a joint committee of trustees from Queen's and Princeton in September 1793, called for the elimination of collegiate instruction in New Brunswick, to be replaced by a preparatory academy. Princeton would maintain a liberal arts college. Under this new arrangement the trustees of both colleges would surrender their respective charters and request a new one, to be issued by the State Legislature of New Jersey. This charter would call for a consolidated board of trustees, to include the governor of the state, the president of the college, and twenty-six members, selected evenly by the existing governing boards of Queen's and Princeton. Only inhabitants of New Jersey would be permitted to serve as trustees on the newly constituted governing body. ${ }^{1}$

The author wishes to thank Drs. Fernanda Perrone and Wendell Piez of Special Collections and University Archives, and Professor Richard P. McCormick for their assistance.

Journal of the Rutgers University Libraries, Vol. LV, No. 2, pp.1-29

Copyright 1993 by the Rutgers University Libraries. All rights reserved. 
This bold proposal created a stir among the Queen's trustees and led to an acrimonious debate within their council. At stake was the very life of Queen's College. By the 1790s, the College of New Jersey and Queen's College, founded within twenty years of each other as the fourth and eighth oldest colleges in the United States, had arrived at a critical stage in their development. The immediate future looked somewhat brighter for Nassau Hall, but Queen's College had reached a point of near collapse.

What events transpired to set the stage for a possible merger? How different were these two New Jersey colleges? What internal and external factors influenced their development? 'The founding and early history of the College of New Jersey at Princeton and Queen's College reflected the broader social, political, religious, and cultural issues of the eighteenth century. Religious upheaval, colonial resistance, and the forming of a new nation all played a significant role in defining each institution.

\section{The Presbyterian Schism and the Founding of the College of New Jersey}

The Great Awakening, a period of tremendous religious and emotional upheaval that swept through the British colonies in the $1730 \mathrm{~s}$, transformed the religious landscape and loosened the conventional structures of colonial society. Culminating in 1739 with the highly "sensational" intercolonial tours of the English evangelist, George Whitefield, the Great Awakening brought about not only enthusiasm and religious revitalization, but also bitter conflict within the Presbyterian and Dutch Reformed Churches, the denominational parents of New Jersey's two colonial colleges.

"New Side" Presbyterian clergymen, as enthusiastic advocates of the revivals, preached a religion marked by a personal experience with God. Often itinerant (and thus without established congregations), they warned of the dangers to religion of an unconverted ministry and called into question the qualifications of "Old Side" anti-revivalist ministers, who preached the gospel without having experienced a personal conversion themselves. To the alarm of the Old Sides, the revivalists encouraged people to evaluate the performance of their ministers, and to pass judgment on their spiritual state. With ardent zeal, they further warned of the horrors of damnation awaiting all those who failed to witness their own personal religious experience. ${ }^{2}$

The revivals raised the essential issue of a learned ministry. A tremendous influx of German, Scottish, and Scots-Irish immigrants into 
the colonies had created a demand for trained clergymen. Prior to the Great Awakening, the Old Side clergy attempted to restrict entry into the Presbyterian ministry by raising the educational standards. In the "trials" that each candidate needed to pass before ordination, the Old Sides emphasized literary accomplishment and proficiency in natural and moral philosophy, as well as extensive preparation in theology. This rigorous procedure of oral examinations often resulted in trials which lasted anywhere from eighteen months to three years. ${ }^{3}$

The Old Side clergy required of all candidates a college degree, but by the 1730s had no way of offering the education themselves. William Tennent's "Log College," first established in 1727, lost its appeal among the conservative clergy after the school became the center of the revival in the middle colonies. ${ }^{4}$ The Old Sides accepted a degree from European universities such as the Scottish academies in St. Andrews, Edinburgh, Aberdeen, and Glasgow, or one from Harvard or Yale, insisting that a rigorous examination administered by the synod would preclude unqualified men from entering the profession. When schism occurred in the Presbyterian Church in 1741, the Synod of Philadelphia, the bastion of Old Side conviction, realized the necessity of establishing an academy as an answer to the Log College, and persuaded Francis Alison to set up a school in New London, Maryland, where he was to teach the classical languages, philosophy, and divinity to aspiring candidates for the ministry. ${ }^{5}$

The New Sides realized that candidates who received their ministerial training in the Log College or from the personal guidance of such evangelicals as the Reverends Samuel Finley, Samuel Blair, Jonathan Dickinson, or Aaron Burr, would have difficulty before a synod committee of Old Side clergy. The newly formed Presbytery of New Brunswick, the governing body for the churches in the Raritan Valley and vicinity, whose members were passionate revivalists, deliberately defied the synod by admitting Log College students or any other candidates whom they thought possessed the proper qualifications. The synod retaliated by expelling the entire New Brunswick Presbytery. Members of the Presbytery of New York issued letters of protest, and when all overtures had failed, they joined forces with their brethren from New Brunswick to form the Synod of New York. ${ }^{6}$

For all their emphasis on emotion and personal conversion, the New Side Presbyterians remained firm believers in an educated ministry, one grounded in classical studies, natural and moral philosophy, as well as divinity. With the death of William Tennent in 1742 and the closing of 
the Log College, they set forth to establish their own institution. "The New Side educational venture," according to Howard Miller, "was impelled by the explosive energy of the revival. The evangelicals' piety, their millennialism, and their emphasis on selfless exertion in the cause of colonial reformation, when institutionalized, proved to be an expansive force in colonial society." "The institutional expression of the revivalists' desire to reform colonial society as well as the principal instrument for realizing those aspirations came in the form of the College of New Jersey, founded in 1746 by members of the New York Synod, with assistance from Gilbert Tennent and other recent graduates of the Log College. The college was founded in particular by Jonathan Dickinson and Aaron Burr, two graduates of Yale who had become disillusioned over their alma mater's recent expulsion of revivalistically inclined students. ${ }^{8}$

\section{The Dutch Response to the Great Awakening}

The Great Awakening also led to division in the Dutch Reformed Church, setting the stage for a series of events that culminated in the birth of a distinct Dutch college in America. Two decades before Whitefield arrived in the colonies, the doctrines which he promoted had been heralded throughout the Province of New Jersey by the Rev. Theodorus Jacobus Frelinghuysen. A graduate of the University of Halle, "the center of a strong pietistic and evangelical movement in European Protestantism," Frelinghuysen had arrived in the Raritan Valley from the Netherlands in 1720 to take charge of the churches in Raritan, New Brunswick, and Six Mile Run (Franklin Park). He soon became the leading figure in the movement among Dutch ministers to gain independence from the Classis of Amsterdam, the governing body of the Dutch Reformed Church. Frelinghuysen's zeal, energy, and determination served as the catalyst for the Dutch ministers in the colonies to challenge the authority of Europe. It was left to his two sons, Theodore and John, to continue the struggle, the former by preaching from his parish in Albany, and the latter by educating those students sympathetic to the revivalistic brand of Calvinism which the elder Frelinghuysen so diligently professed. ${ }^{9}$

The immediate concern in the Dutch Church was the lack of authority within the American churches to ordain and educate ministers in the colonies. The proliferation of churches resulting from the revivals created a severe shortage of ministers available to preach the gospel. There were, for example, only twenty ministers in the 1740 s to direct the 
religious activities of the Dutch population in the American provinces, and by 1771, when Queen's College commenced instruction, only fortyone were available and the number of churches had expanded to one hundred..$^{10}$ Those who aspired to the pulpit were required to embark on a long, arduous, and expensive journey to Amsterdam for their training.

There had been growing agitation within the Dutch Reformed churches in the colonies for some kind of agency with at least limited powers to educate and ordain ministers for the pulpit. The Classis of Amsterdam vacillated on the question for a number of years, but in 1747 reluctantly gave its approval for the formation of such a body, which was called a "coetus." Though the coetus hoped to gain some autonomy in ecclesiastical affairs, the Classis of Amsterdam severely limited its authority to the examination and ordination of ministers under special circumstances; ultimate authority in colonial church government remained in the Netherlands. Discontent among members of the coetus over these restrictions led to a movement to establish an American classis, with the power to ordain ministers for the Dutch churches. With such authority, the classis would also attempt to establish a professorship of theology, or even more ambitiously, create a distinct Dutch academy in the provinces.

Severe opposition to the formation of an American classis came from members of the consistory of the Dutch Reformed churches in New York City, who contested any attempt to break formal ties with foreign authority, and who feared the decline of Dutch tradition in the church and in the colonies, especially the use of the Dutch language. Equally alarming to the consistory was the thought that a local classis could intrude into its own affairs much more efficiently than one which governed from Amsterdam. They formally rejected the proposal for a classis in a meeting in October 1754, citing their opposition to the "New Side" convictions of Theodore Frelinghuysen, leader of the pro-classis forces. The ensuing controversy between the two factions in the church, similar to that which occurred among the Presbyterians, ultimately led to the founding of a Dutch college in New Jersey.

Dissension heightened between the coetus and the consistory in 1755 over a petition to appoint a Dutch professor of divinity in King's College (Columbia), which had received its charter from the New York State Legislature one year earlier. The consistory, initially opposed to any sectarian alliance of King's with the Anglican Church, suddenly shifted its allegiance to support the proposal and to voice opposition to creating an American classis. They formed an opposing group to the 
coetus known as a "conferentie." The principal adversary was the Reverend Johannes Ritzema, pastor of the Dutch Reformed Church in New York City and trustee of King's College, who made it known that he desired the professorship. ${ }^{11}$ The seed of discontent had been sown, prompting the Reverend Theodore Frelinghuysen to leave his pulpit in Albany to rally the ministers and congregations throughout the Hudson Valley into action.

Convening in New York City in May 1755, the coetus formulated plans to appeal to the Synod of Holland in favor of forming an American classis "as well as an Academy, where our youth, who are devoted to study, may receive instruction." It selected Frelinghuysen to present a petition, which declared:

Inasmuch as it is expedient for the glory of God, and conducive to the salvation of men, to establish in these recently inhabited ends of the earth Seminaries of True Philosophy as well as of sound doctrine, that men may be imbued with the principles of wisdom, virtue, and unostentatious piety: Therefore, we, pastors and elders of both provinces-viz. of New York and New Jersey, in America-being assembled in a Coetus, and having established an alliance among ourselves, do resolve in these critical times to strive with all our energy, and in the fear of God, to plant a university or seminary for young men destined for study in the learned languages and liberal arts, and who are to be instructed in the philosophical sciences; also that it may be a school of the prophets in which young Levites and Nazarites of God may be prepared to enter upon the sacred ministerial office in the church of God. ${ }^{12}$

Frelinghuysen embarked from New York City to the Netherlands in October 1759 , stayed for two years, and obtained promises of financial support, but failed in his mission. It could not have been unexpected. Frelinghuysen had come before the classis as a representative of a church divided against itself. Letters from Ritzema and other members of the conferentie had counseled against any formal Dutch institution on American soil. ${ }^{13}$ There was undoubtedly a concern over where the money would come from to support such an institution; surely Holland could not look favorably upon providing such assistance to a schismatic faction of a distant provincial church. Rebuffed by the Classis of Amsterdam, Frelinghuysen set sail for the colonies in 1761; as his vessel approached New York Harbor, he mysteriously perished at sea. It was left to others in the church to carry on his vision of a Dutch college.

By this time Jacob Hardenbergh had established himself as a formi- 
dable coetus leader and a staunch supporter of the establishment of a Dutch college in the colonies. In 1763, he traveled to Europe to renew the cause for independence before the Amsterdam Classis. Rejected by the classis, Hardenbergh decided to collect the funds that had been promised to Frelinghuysen, thereby further antagonizing the authorities in Amsterdam. Hardenbergh informed the classis of efforts in the colonies to appeal to King George III of England for a charter to establish a Dutch academy. Previous requests to the Royal Governors of New Jersey had failed, but on November 10, 1766, William Franklin, Provincial Governor of New Jersey and the son of Benjamin Franklin, granted a charter for Queen's College, named in honor of Charlotte, the Queen Consort. ${ }^{14}$

\section{Secular Governance of the Denominational Colleges}

Though religious motives had been dominant in the founding of the College of New Jersey and Queen's College, with the principal intention of educating future ministers in the Presbyterian and Dutch Reformed Churches, neither institution could be considered in the strictest sense denominational colleges. Their charters were highly secular documents which stated the purpose of each institution as "the Education of Youth in the Learned Languages and in the Liberal Arts and Sciences." "The phrasing," according to George P. Schmidt, "was almost identical for both institutions, except that the Queen's charter added the term 'useful' after 'Liberal'," an expression which would assist the trustees a century later in arguing its case against Princeton for the Land Grant status of New Jersey. ${ }^{15}$ While the intent of educating youth for the ministry is explicitly stated in the charter for Queen's College, no such mention is found in that of the College of New Jersey. ${ }^{16}$

Both institutions were to be governed by a board of trustees that included the Provincial Governor, Council President, Chief Justice, and Attorney General of New Jersey. The governing body of the College of New Jersey consisted of twenty-three members and its composition was interdenominational. Included along with the New Side Presbyterians were members of the Dutch Reformed and Anglican churches and two Quakers, all drawn from the middle colonies. Forty-one members were appointed to govern Queen's College, of whom thirteen were ministers of the Dutch Church and four were state officials. The Queen's charter limited clerical representation on the board to one-third of the membership; that percentage from the beginning was dominated by Dutch clergymen. The initial Trustees of Queen's came predominately from 
the Provinces of New Jersey and New York, where the majority of the Dutch population had settled. At the College of New Jersey, neither a percentage of the trustees nor the president of the college was required to be Presbyterian. At Queen's, the trustees were to appoint a president, who was to be a member of the Dutch Reformed Church. While the charter specified no ecclesiastical control over the college, provision was made for the appointment of a professor of divinity. One particularly interesting provision in the Queen's charter was directed at the Dutch population in the colonies:

It is hereby declared and expressly enjoined that there shall always be, residing at or near such college, at least one professor or teacher well versed in the English language ... grammatically to instruct the students of said college in the knowledge of the English language. ${ }^{17}$

\section{The College of New Jersey - The Formative Years}

The College of New Jersey began operations in Jonathan Dickinson's church in Elizabethtown, New Jersey, in May 1747. Within four months Dickinson died, and the college moved six miles north to Newark, where the undergraduate students assembled under the tutelage of the Reverend Aaron Burr. The college held its first commencement on November 9, 1748, awarding six degrees to baccalaureate candidates, and the degree of master of arts to Jonathan Belcher, governor of the province and fervent supporter of the college. ${ }^{18}$ Earlier in the day, the trustees unanimously elected Aaron Burr as the college's second president. Burr's leadership proved to be decisive during the next ten years, placing the college on a firm foundation for its ensuing development.

The early success of the college placed a financial strain on the trustees, who set in motion a plan to raise funds to erect a college building and a president's house in a new and permanent location. Burr's congregation voiced its approval for continuing the college in Newark. But, according to Samuel Blair, the temptations of this small city presented too many dangers to the "morals and literary improvements of the youth" to be tolerated. ${ }^{19}$ The trustees were prompted by Governor Belcher and leaders of the Scots-Irish contingent of the Philadelphia Synod to consider the town of New Brunswick or the small village of Princeton, both centrally located, and far removed from the college's Anglican rival, King's College in New York. ${ }^{20}$

The trustees chose to have the two towns demonstrate their ability to support the college by contributing $£ 1,000$, ten acres of land for the 
campus, and 200 acres of woodland to provide fuel. Though New Brunswick fell short of the requirements, Princeton was able to secure the necessary subscriptions. With the completion of Nassau Hall the college moved in the fall of 1756 to the rustic village of Princeton, the center of New Side Presbyterianism.

From sparse beginnings, with one tutor and a handful of students, a small endowment, with no lecture hall, library, equipment, or dormitory, the College of New Jersey suddenly found itself situated in a magnificent edifice, with three tutors and around seventy students. But fate soon struck the young college. In less than a decade, it lost four presidents. Aaron Burr died in September 1757, one year after the college occupied Nassau Hall. Jonathan Edwards, the noted New England theologian, staunch revivalist, and Burr's father-in-law and successor, suffered a fatal reaction to a small pox inoculation after residing in Princeton for only six weeks. The trustees turned to Samuel Davies, the New Side Presbyterian leader of Virginia, who along with Gilbert Tennent had helped to raise funds in Great Britain for the college. $^{21}$ Unfortunately, Davis' tenure lasted less than two years; he died in February 1761 at the age of thirty-seven. Samuel Finley, a prominent clergyman, early leader of the Great Awakening, and head of a preparatory academy in Nottingham, Maryland, presided over the expansion of the college from 1761 to 1766 , when his own untimely death marked the end of an epoch in the early history of Princeton. During the next two years the trustees sought to persuade the eminent Scot divine, Jonathan Witherspoon, to accept the presidency. Witherspoon finally accepted and arrived in Princeton in time for the commencement exercises of 1768 , inaugurating an important new era in the history of the college, one that would gradually change the direction of the College of New Jersey.

By 1748 Burr had codified the requirements for admission and included them in his "Laws and Customs of the College." All prospective candidates were expected to be rigorously examined by the president and the tutor or tutors in Latin and Greek. They had to "Render Virgil and Tully's orations into English and to turn English into true \& grammatical Latin \& be so well acquainted with the Greek as to render any part of the four Evangelists in that language into Latin or English \& to give the grammatical Construction of the Words." 22

Instruction in the college under Princeton's first three presidents resembled in many ways the Log College. Prospective ministers would gather around their mentor to study the classical languages and theol- 
ogy. As graduates of Yale, Dickinson, Burr, and Finley were undoubtedly influenced by the curriculum offered at their alma mater. The course of study at Yale called for Latin, Greek, Hebrew, and elementary mathematics during the student's first year. In the second year they would continue their study of the ancient languages, and were also introduced to logic, rhetoric, oratory, geography, and natural philosophy, with some advanced work in algebra and trigonometry. By the third year, the students continued concentrating on natural philosophy and mathematics with some obtaining mastery in conic sections and differentials. In their senior year, students recited in metaphysics, ethics, and divinity. Debating also became part of their collegiate life in the two upper classes. ${ }^{23}$

The curriculum at Princeton is best illustrated in letters written by Joseph Shippen to his father during the student's four years at the College of New Jersey in Newark under President Burr (1751-1754). In his first year the young Shippen read Xenophon in Greek and Cicero's de Oratore in Latin, studied Hebrew grammar, read Watt's Logic, and was introduced to some geography, astronomy, and rhetoric. In the following year he continued his study of the classical languages with Cicero's Orations, Horace, and Homer, and took advanced classes in "natural philosophy" by studying astronomy, based on Benjamin Martin's Philosophia Brittanica, a New and Comprehensive System of the Newtonian Philosophy, Astronomy, and Geography, with Notes. An added feature to his astronomical studies was the opportunity to conduct rudimentary experiments. The languages were no longer of primary concern during Shippen's junior year, as they were replaced by extensive study of natural philosophy and the introduction of ethics and moral philosophy. His senior year was devoted to the study of moral philosophy and a review of the work from the past three years. ${ }^{24}$

The curriculum of the College of New Jersey, albeit a traditional course of study found in the other colonial colleges, formed the intellectual foundation "to produce selfless rulers for a reformed colonial society." At the core was the determination to "promote piety and inculcate virtue." Any problems associated with promoting both these ideals, according to Howard Miller, could be surmounted in a college "rightly conceived and correctly administered."

The New Side educators believed that at Princeton they could balance piety and learning, that they could protect their charges from the dangers of their parents' indulgence and the village's temptations, that they could 
prepare their students for a life of extensive usefulness. That confidence, in part, measured the evangelical educators' confidence in the curriculum they created at Princeton. To be sure, much of that course of study was traditional, some borrowed from Yale, much more from the Scottish universities, and probably less than has been believed from the dissenting academies of England. But the New Side Presbyterians at Princeton did innovate, and their tentative changes were pregnant with implications for the future..$^{25}$

From humble origins in Dickinson's church in Elizabeth, the College of New Jersey developed in less than two decades into one of the largest and most influential institutions of higher learning in Colonial America. It stood third behind Harvard and Yale in the total number of degrees conferred between the years 1748 and $1768 .{ }^{26}$ The College fulfilled the vision of its founders to become intercolonial and cosmopolitan. Over 90 percent of Harvard's students came from Massachusetts, three-quarters of the students attending Yale were from Connecticut, and nearly all new students at William and Mary resided in Virginia. Princeton, however, attracted students from New England, the middle colonies, and the south. In fact, as James McLachlan contends, "the College of New Jersey was on the way to becoming a national institution well before there was a nation." McLachlan suggests four reasons for Princeton's cosmopolitan makeup. First, as a product of the Great Awakening, the college drew not only from a constituency of New Side Presbyterians, but also attracted "New Light" Congregationalists from New England who had become philosophically dissatisfied with Harvard and Yale. Second, the location of Princeton at the "demographic center" of the Northern and Southern colonies made it readily accessible. Third, the college early on adopted a policy of admitting students to advanced standing more willingly than Harvard or Yale. And finally, the College of New Jersey's tuition throughout its first two decades was the lowest among the colonial colleges, while the expenses for students living in Princeton were substantially lower than for those who resided in New York, Cambridge, New Haven, Philadelphia, or Williamsburg. ${ }^{27}$

The primary objective of the College at Princeton, according to its New Side Presbyterian founders, was to facilitate ministerial education. "The great \& chief design of erecting the College," Dickinson had announced, "is for the education of pious \& wel [sic] qualified Candidates for the Ministry, that vital peity [sic] may by that means be promoted in our Churches, and . . . Religion may be transmitted to 
Posterity." ${ }^{28}$ Though it never lost sight of the need to produce clergymen among its students, between 1748 and 1768 , the college emerged as a "preprofessional" school, an institution which trained students not only for the clergy, but for the law and medicine as well. Eighty percent of the students who graduated during this period found their primary occupations as clergymen, lawyers, or physicians. Among the 158 destined for the ministry, 97 became Presbyterian clergymen, 41 occupied Congregational pulpits, and the remainder were dispersed among the other Protestant denominations. ${ }^{29}$

While Princeton was certainly identified as a Presbyterian college throughout the colonies, its founders never envisioned it as rigidly sectarian. In fact, the college received very little support from the Presbyterian Church, and what financial assistance was forthcoming was usually in the form of gifts made by the synod to support "poor and pious youth" who were studying for the ministry. ${ }^{30}$ In its charter, the college encouraged all students to attend, "any different sentiments in religion notwithstanding." While Presbyterians were in the majority, the college could count a large number of Congregationalists, Anglicans, Baptists, Dutch Reformed, and Lutherans among its students throughout the eighteenth century. ${ }^{31}$

With the arrival of John Witherspoon in 1768, the College of New Jersey had acquired as its president one of the most influential and respected leaders of the Church of Scotland. A noted theologian and philosopher, who was not a party to either faction of the American Presbyterian Church, Witherspoon would gradually separate Princeton from its attachment to the heritage of the Great Awakening. As an educator, according to Richard Harrison, Witherspoon would "proceed under the assumption that learning had both a utilitarian component and a moral component and he would inculcate in his pupils his insistence that they live useful as well as moral lives." 32

Witherspoon wasted no time in establishing his role as leader of the college. Following the commencement ceremonies in 1768 , he undertook a personal tour of New York, Pennsylvania, and New England to solicit funds and recruit students for the college. While his success was severely limited due to competition for money from other colonial academies, Witherspoon nevertheless established immediate rapport with New Side Presbyterians and New Light Congregationalists. He realized that there were untapped sources elsewhere in the provinces and turned toward the south in 1769 and again in 1770, where he made the acquaintance of prominent Virginia families, including the Madisons, 
the Lees, and the Washingtons. In addition to raising funds and attracting students from the region, Witherspoon solidified his role as a "friend of religion."

At home Witherspoon was concerned with the academic standards in the College of New Jersey. He immediately took personal charge of the college grammar school, introducing new methods of instruction in Latin, geography, arithmetic, and the English language, with the intent to elevate the standing of prospective students to Princeton. In the college itself, entrance examinations were to be strictly enforced and any student aspiring to advanced standing was required to take the commencement examination of the next lowest class. ${ }^{33}$

In an attempt to broaden the college's appeal, the trustees suggested that Witherspoon travel to the West Indies, where he was revered as a "great scholar and divine." Though Witherspoon declined to make such a long and dangerous voyage, he did publish a brief sketch of the college, its history, educational methods, purposes, and needs, for distribution throughout the islands. This account provides us with details concerning the course of study at Princeton under its sixth president. "The regular course of instruction is in four classes," Witherspoon wrote,

exactly after the manner, and bearing the names of the classes in the English universities: Freshman, Sophomore, Junior, and Senior. In the first year they read Latin and Greek, with Roman and Grecian antiquities, and rhetoric. In the second, continuing the study of languages, they learn a complete system of geography, with the use of the globes, the first principles of philosophy, and the elements of mathematical knowledge. The third, though the languages are not wholly omitted, is chiefly employed in mathematics and natural philosophy. And the senior year is employed in reading the higher classics, proceeding in the mathematics and natural philosophy, and going through a course of moral philosophy. In addition to these, the President gives lectures to the juniors and seniors, which consequently every student hears twice over his course, first upon chronology and history, and afterwards upon composition and criticism. He has also taught the French language last winter, and it will continue to be taught to those who desire to learn it. ${ }^{34}$

The curriculum at Princeton was broadened and more sharply defined under Witherspoon, but it was relatively consistent with the institution's past concerns. The subjects on which he lectured-moral philosophy, divinity, history, and eloquence-were all well established in the college by his predecessors. But it was in this venue that 
Witherspoon was able to introduce political theories to his charges. One contribution, drawn from his experiences in the Scottish universities, was the introduction of the lecture method, which required students to make their own personal copy of a syllabus or course outline, that the president had first prepared. The syllabus served as a basic text to be elaborated upon during the class session. But there was more than pedagogical interest in his lectures.

Whether he lectured on moral philosophy, history, or ethics, Witherspoon expounded upon his philosophy of natural realism, the Scottish reaction to the philosophical idealism of Bishop George Berkeley and the skepticism of David Hume. When he arrived at Princeton in 1768 , Witherspoon discovered the reigning philosophical system at the college was Berkeleyean idealism. According to Ashbel Green, "The Berklean [sic] system of Metaphysics was in repute in the college when he entered on his office. The tutors were zealous believers in it, and waited on the President, with some expectation of either confounding him, or making him a proselite [sic]. They had mistaken their man. He first reasoned against the system, and then ridiculed it, till he drove it out of the college." ${ }^{35}$ As a result all the tutors serving under Witherspoon soon left Princeton. This change of intellectual activity amounted to nothing less than a shift away from the philosophical foundation of New Side revivalism. In effect, Witherspoon's insistence on emphasizing empiricism over orthodoxy turned Princeton into the center of the Scottish Enlightenment in America. ${ }^{36}$

Witherspoon was concerned with scientific instruction in the college and he was particularly proud of the scientific apparatus that the college was able to obtain with the funds he helped raise. In 1770 the trustees authorized the purchase of "Philosophical Apparatus" and appointed a tutor, William Churchill Houston, as librarian and curator. One year later Houston was appointed as the first professor of mathematics and natural philosophy at Princeton. Witherspoon also purchased David Rittenhouse's orrery, a working model of the universe that greatly enhanced instruction in astronomy. ${ }^{37}$ By 1772 Witherspoon could proclaim that the college's program in science was "equal, if not superior, to any on the continent." ${ }^{38}$

The College of New Jersey at Princeton on the eve of the American Revolution proceeded to graduate one-fifth of all students who received bachelor's degrees in American colleges, third to Harvard and Yale. ${ }^{39}$ It continued to be the most diverse and cosmopolitan of all American institutions. One significant change that occurred was that, while New 
Jersey, New York, and Pennsylvania continued to supply the greatest number of students, the south had by now replaced New England as the second richest source of students. Of those who graduated between the years 1769 and 1775 , nearly one-half were to become ordained ministers, a proportion second only to Dartmouth College. But the number of students who became Presbyterian clergymen increased significantly from those who graduated in the first two decades of the college. This can be attributed to the fact that by 1769 the church had become reunited. In addition, the appointment of Witherspoon as president of the college was welcomed by both New Side and Old Side clergymen. His prestige undoubtedly attracted prospective ministers and fostered greater denominational influence on the college. "Insofar as it served as a seminary for future clergyman," asserts Richard Harrison, "Princeton was on the way to becoming more sectarian as the Revolution approached." 40

\section{Launching Queen's College}

When the Trustees of Queen's College convened for their first meeting in Hackensack in May 1767, Jacob Hardenbergh took his place along side the other Dutch ministers who had been most active in the founding of the college. Launching the new institution proved to be as difficult as securing its charter for Hardenbergh and his brethren. In fact, five years went by before Queen's College became operational. Several obstacles presented themselves from the outset. The original charter, a copy of which has never been found, presumably included features which were unacceptable to the trustees. Prominent among them was a distinction between residents and nonresidents of New Jersey that complicated the trustees' ability to raise funds for the college in the state of New York. After repeated efforts by the trustees to amend it, a new charter was issued by Governor Franklin on March 20, 1770. It is under this charter that Rutgers has since existed. ${ }^{41}$

With an adequate charter obtained and the governing board assembled, the trustees turned to selecting a site for Queen's College, an issue that divided the trustees. The choice was between Hackensack and New Brunswick. Hardenbergh reminded his colleagues how Princeton had been chosen over New Brunswick for the College of New Jersey in 1752 , when its representatives offered a more favorable grant of land and money, and he suggested that the same method be employed for Queen's College. The Reverend John H. Goetschius, an early advocate for the college, had begun an academy in Hackensack and 
claimed that as an advantage for establishing the college in Bergen County. But the supporters of New Brunswick reminded their colleagues that the Reverend John Leydt of New Brunswick had joined with Hardenbergh and other members of that community to establish a grammar school in $1768 .{ }^{42}$ Four years passed before the trustees met in May 1771 to present their subscriptions and choose the location for the college. A vote of ten to seven placed the college in New Brunswick.

By October 1771 the trustees were prepared to open Queen's College. They had acquired the "Sign of the Red Lion," a former tavern located on the corner of Albany and Neilson streets in New Brunswick, which housed the students of the college and the grammar school, as well as Frederick Frelinghuysen, grandson of Theodorus Jacobus Frelinghuysen and a Princeton graduate (Class of 1770), who was the unanimous choice of the trustees to serve as tutor. In November, Frelinghuysen commenced instruction "to cultivate Piety, Learning and Liberty" among the first students of the college. ${ }^{43}$

The curriculum of Queen's College was modeled on that of Princeton and the other colonial colleges of the time. The plan of education, published in the Rules and Regulations for the Government of Queen's College (1787), informs us that prospective candidates for admission to the college were required to be able to "render into English, Caesar's Commentaries of the Gallick [sic] War, some of Cicero's Orations, the Eclogues of Virgil, one or more of the Aeniads; and at least one of the Gospels from the Greek." As for the curriculum:

In the progress through the four different classes of the College they shall read in Latin, the principal Orations of Cicero, Virgil, and Horace; in the Greek Language, they shall read such parts of the Greek Testament as the President and Tutors shall direct; Xenophon's Cyropaedia, Homer and Longinus; they shall also read Kennet's Antiquities, Logick [sic], Geography, Rhetoric, Arithmetic, Algebra, Euclid's Elements of Geometry, Trigonometry, Navigation and Surveying, Natural and Moral Philosophy, and English Grammar, and composition to be attended to in the respective classes. ${ }^{4}$

While Princeton went through a succession of presidents during its early years, Queen's College went for over a decade without one. Governance remained in the hands of the trustees' committee which assisted Frelinghuysen with directing the business of the college until a suitable president could be secured. It is clear why Queen's failed to attract an appropriate candidate. In a letter written to the Classis of 
Amsterdam in 1772, the trustees stated the qualifications which such person should possess. The president of Queen's College was also to be the professor of theology. He was to be responsible for overseeing the tutors of the college in their instruction of languages. As pastor of a congregation, the President was to conduct "ministerial duties on the sabbath." He was to be of "extreme piety and thoroughly learned, good natured and free and friendly in conversation." He was to be, most importantly, a master of the English language. The president was to abide by the Constitution of the Church of the Netherlands, and "welcome the opportunity to lecture on Marckii Medulla Theologia Christiana." 45

Queen's College grew slowly over the next few years, and by 1774 , when the first commencement was held, there were over twenty students enrolled. The Reverend Jacob Hardenbergh, staunch and dedicated proponent of Queen's College, presided over the memorable event and conferred on behalf of the trustees the first and only degree of the day to Matthew Leydt of New Brunswick. In his commencement address, Hardenbergh extolled "that men of Learning are of absolute necessity and extensive advantages to Society." Demonstrating the usefulness of higher learning in preparing men for public life as well as for the learned professions of law, medicine, and theology, he encouraged those who had assembled to continue their moral and financial support by sending their children to the college, reflecting on "how reasonable and necessary it is, that the Community should promote and Incourage [sic] the Seats of Learning...." Hardenbergh, an ardent patriot who was to play a significant role in the American Revolution, took the occasion to remind his audience of the troubled times in which they lived. "O! may America never want Sons of consumate Wisdom, intrep'd Resolution and true piety to defend her civil and Religious liberties, and promote the public weal of the present and rising Generation!" 46

\section{From Citadels of the Great Awakening to Seminaries of Sedition}

As the revolution approached, the students of the College of New Jersey and Queen's College voiced with increased frequency their ardent patriotism. There were very few loyalists among the students and faculty. The two schools, along with Yale, were the strongest colonial institutional supporters of resistance to Great Britain. The injustice of the Stamp Act, the right to resist royal aggression, and the Boston Massacre, all were discussed among students and citizens of 
Princeton and New Brunswick. By 1766, commencement at the College of New Jersey had become the occasion for harangues on patriotism and aspects of civil liberty. A year earlier, in defiance of the Stamp Act, the graduating class assembled to receive their degrees attired in cloth of American manufacture. In July 1770, Princeton students intercepted a letter written by a group of New York merchants to those of Philadelphia, declaring their intention to ignore the recently enacted NonImportation Agreement. The students gathered on the college grounds and with the assistance of a public hangman, burned the letter as a warning to all "betrayers of their country." As relations between the colonies and Great Britain withered, the students became bitterly partisan. Those students who possessed Tory sympathies were heckled and even ducked under the college water pump by their classmates. In January 1774, the students held a "tea party" on the campus, burning the college's winter supply of tea. When an effigy of Massachusetts' governor Thomas Hutchinson was burned on the college grounds, President Witherspoon and the faculty did nothing to punish the demonstrators, confirming that the entire college community was committed to the American cause. When conflict erupted at Lexington and Concord, the students formed their own militia. ${ }^{47}$

Discussions on topics pertaining to the revolution took place at Queen's College during meetings of the Athenian Society, a student literary society established shortly following the opening of the college. Recorded throughout the minutes of the society are frequent references to speeches on liberty, "the future Glory of America," and readings on patriotic themes. "General Howe with the British Fleet arriving at Sandy Hook," read the entry for June 29, 1776. "All the Members of the Athenian Society who were able to bear Arms immediately marched to oppose the Enemy. Matters being thus in Confusion, July the 27th the College was suspended to the 21st of October." The following passage appeared at the end of the recorded deliberations for November 20 , 1776:

The British Army under the command of General Howe having invaded the State of New Jersey, and penetrating as far as the City of New Brunswick on the first day of December in the Year 1776. The members of the Athenian Society still inspired by Patriotism, and zealous to promote the interests of America, leaving their peaceable abodes, again assisted their Countrymen to repel an Enemy endeavoring to establish a System of Tyranny and Oppression. ${ }^{48}$ 
In 1777, during the British occupation of New Brunswick, Queen's College tutor John Taylor gathered a half-dozen students in an abandoned church at North Branch to resume their studies. Called into active service, Taylor was replaced by John Bogart, one of the first alumni of Queen's, who directed the college until Taylor returned in 1779. The college relocated to Millstone the following year and eventually was able to return to New Brunswick in the spring of 1781. It was also during the college's stay in North Branch and Millstone that the students revived their cherished Athenian Society. ${ }^{49}$

The revolution disrupted the operations of the College of New Jersey as well. As General Howe advanced along the highway toward New Brunswick and Princeton, Witherspoon suspended instruction in the college at the end of November 1776. The British soon occupied Nassau Hall as a barracks and a stable. They stripped the chapel for firewood and plundered the libraries of the president and the college. With the victory of Washington's men at Princeton, Nassau Hall for over a year served as home to a group of Continental troops who "conducted themselves more like a swarm of vandals than the defenders of liberty." 50 It then became a hospital and was not returned for use by the college until much later in the war.

Caught up in the spirit of the times, students, faculty, presidents, and trustees alike joined in the struggle for independence. John Witherspoon, perhaps the college president most active in the political affairs of his time, served initially as a member of the Somerset County Committee on Correspondence, and joined the provincial convention, where he played a leading role in the overthrow of the royal government and the imprisonment of Governor William Franklin. He was selected as a New Jersey delegate to the Continental Congress, and became the only clergyman to sign the Declaration of Independence. Witherspoon continued to conduct the affairs of the college while serving in the Continental Congress from 1776 to 1783.

As the revolution approached, Queen's College trustee Jacob Hardenbergh likewise became an outspoken proponent for American independence. According to one writer, he "took no pains to conceal his opinions," and frequently "stirred up the people through the pulpit ministrations of the sanctuary, arousing their enthusiasm and encouraging them in their determination to achieve their country's independence." He was a delegate to the last Provincial Congress, which met in Burlington in June 1776 to ratify the Declaration of Independence and frame the constitution of the state of New Jersey. He served several 
terms in the General Assembly, where his colleagues "testified their confidence in his political wisdom and patriotism by appointing him chairman of important committees and intrusting to him much of the business of legislation." 51

Hardenbergh was considered among "the warmest friends of liberty" throughout the revolution. During the campaign in New Jersey in the winter of 1779 , he befriended General Washington, whose army was encamped within the area of Hardenbergh's congregation. Washington's headquarters was located next door to his home and the two men visited frequently. His public zeal on behalf of the resistance against British rule provoked the enmity of his Tory neighbors and his life was often endangered. The British considered Hardenbergh a menace and offered a $£ 100$ reward for his capture, and he was obliged to sleep with a loaded musket at his bedside, and several times flee from his home, "fully armed, and to roam about the country, to prevent being seized by the Tories." On the evening of October 26, 1779, a company of the Queen's Rangers, under the command of Lieutenant-Colonel Simcoe, burned to the ground his church at Raritan during a raid through Somerset County. For several years his congregation gathered together for worship in a small dwelling nearby, awaiting the rebuilding of a new church edifice.

Others associated with Queen's College played instrumental roles. Frederick Frelinghuysen, the first tutor of Queen's College, served as a major of the Minute Men, captain of artillery, and then colonel and aide-de-camp to General Philemon Dickinson in the Continental Army. John Taylor, Frelinghuysen's successor as tutor in 1773, was a colonel in the militia. And Simeon DeWitt (Class of 1776) became General Washington's chief geographer and conducted a survey of the road to Yorktown. ${ }^{52}$

\section{Educating Republicans}

The post-Revolutionary era at the College of New Jersey was marked by an exuberance over independence and the future that awaited the new nation. Excited by the move of Congress from Philadelphia to Nassau Hall in 1783, students, faculty, and trustees alike rejoiced in the dawning of a new age. The college was the scene of emotional Fourthof-July celebrations, complete with rousing oratory. By the early $1790 \mathrm{~s}$, the speeches cheered the spirit of enlightenment seen in the French Revolution. But the atmosphere at Princeton was also tempered by the uncertainties facing the college. The biggest problem was financial. 
Nassau Hall remained in ruins, and the trustees' several requests for compensation from Congress finally were fulfilled in the amount of $\$ 19,357$ (Continental), money worth about 5 percent of its face value. The board dispatched the president and Joseph Reed to Great Britain to raise money to increase an endowment that had become greatly diminished due to the college's investment in depreciated Continental securities. Witherspoon, confronting continued hostility among the English, returned with the paltry sum of $£ 5$ for the treasury. The college, forced to sell its valuable woodlot for $\$ 1,200$, turned to the Presbyterian church for additional support to get through the decade of the $1780 \mathrm{~s}^{53}$

The college showed signs of a modest recovery as it entered the 1790 s. By this time declining health had limited Witherspoon's role in the college, and leadership fell into the hands of his son-in-law, Samuel Stanhope Smith, who had joined the faculty in 1779. The trustees soon appointed Smith vice-president in 1786, and chose him as Witherspoon's successor following the president's death in 1794. The college, which witnessed a decline in enrollment during the immediate post-war years, regained strength and began producing graduates at numbers comparable to its pre-Revolution rate. Between 1776 and 1783, the College of New Jersey awarded only 82 of 825 degrees conferred by American colleges, falling to fourth behind Yale, Harvard, and Dartmouth. The war damage suffered by Princeton was substantially more than any institution in New England. But by 1794 Princeton had increased the number of graduates for the ten-year period (1784-1794) to 246 degrees, and in the process closed the gap with Yale, Harvard, and Dartmouth for the period 1791 to $1794 .^{54}$

One significant shift that occurred in the College of New Jersey during the post-war era was in the occupational choices of its graduates. The number of students who chose to enter the ministry had steadily declined during the war years. That decline continued in the early years of the 1790s. From 1791 through 1794, out of 110 graduates of the college, only 16 went on to become ordained clergymen, or 14 percent. When compared with the percentage of students entering the ministry prior to the war ( 48 percent), it is readily apparent that Princeton had changed from a "citadel of the First Great Awakening" to a school that cultivated not just piety and virtue, but also the values of republicanism. ${ }^{55}$

The most pressing issue facing Queen's College following the Revolutionary War was the lack of leadership. The trustees of the college continued their search for a president with the assistance of a now 
reunited Dutch Church. In 1786 they finally appointed the ever faithful Jacob Hardenbergh, who accepted the presidency of the college and the pastorate of the church at New Brunswick. Queen's College prospered during the next four years under the leadership of Hardenbergh. With assistance from the trustees and ministers in the area of New Brunswick, he campaigned for additional subscriptions to meet expenses and paved the way for attracting funds to erect a new home for the college on George Street, which was fully occupied by 1791 . Enrollment climbed slowly; in 1789 the graduating class of the college included ten students. Hardenbergh reported to the Synod that year on the progress of the institution but also cautioned that more was needed in the way of financial support to continue its operation. The college had run a significant deficit and the salaries owed to both the President and the tutors had gone unpaid. But before the churches could come to the aid of the college, Hardenbergh succumbed to tuberculosis and died on October 30,1790. Queen's College had lost its most loyal friend and staunchest supporter.

With the death of Hardenbergh, Queen's College fell upon hard times. Its erstwhile tutor Frelinghuysen had departed, as did John Taylor, who assumed charge of an academy in Elizabeth; he subsequently joined with Reverend Dirck Romeyn to commence instruction in the Union Academy in Schenectady, soon to become Union College. Their place was taken by a succession of tutors over the next several years, including Charles Smith, a 1786 graduate of Princeton. The trustees searched for a successor to Hardenbergh, and once again forwarded the names of John Henry Livingston and Dirck Romeyn, both of whom again declined the offer. In the interim, the trustees appointed the Reverend William Linn to preside at the commencements of 1791 and 1792. A gifted preacher, whose eloquence was described as of "a most ardent and impassioned kind," William Linn graduated from the College of New Jersey in 1772. ${ }^{56}$ He had been appointed a trustee of Queen's College in 1787, and assisted Jacob Hardenbergh with securing subscriptions for the new college building. When adequate funding for the college appeared remote, Linn debated with his fellow trustees the merits of merging the college with that of Princeton.

\section{The Proposed Merger of 1793}

When the trustees of Queen's College convened in October 1793 to discuss the proposed merger with the College of New Jersey, they 
clearly recognized that the institution's fate was in their hands. From its inception, the college had been troubled by inadequate finances to operate efficiently. Its ties to the Dutch Reformed Church were tenuous, with the burning issue of the professor of theology always at the center of the debate. Undoubtedly, the trustees viewed the prospects of merging with Princeton as a favorable solution to their continuing difficulties. There would be distinct advantages for Queen's College. The College of New Jersey was an elite institution founded by New Side Presbyterians on principles similar to those which brought Queen's into existence. Throughout the eighteenth century the College at Princeton attracted students in far greater numbers than did the college at New Brunswick. Princeton was a national institution, with students coming from every state in the nation; Queen's was considerably smaller, drawing students primarily from the areas of Dutch concentration in New Jersey and New York. Between 1771 and 1794 Princeton graduated 375 students, as opposed to 74 from Queen's College. By the 1790s most of Princeton's graduates were entering the legal profession and engaging in public life, a significant shift away from the college's initial objective of training ministers for the Presbyterian church. By contrast, nearly one-half of Queen's College graduates chose to become ordained ministers, and over 70 percent of these became Dutch Reformed clergymen. Queen's College maintained closer ties to the Dutch church, partly out of necessity. ${ }^{57}$

But there were members of the Queen's board who firmly wished to maintain the independence of the institution which they helped build. Some questioned the legality of a merger with Princeton. Could the trustees surrender their charter? How would such a merger be received by all those who had invested in a Dutch college? There were others who suggested an alternative plan of merger that was directed toward easing the tension between the college and the Dutch Reformed Church. This plan proposed that Queen's College become a theological academy that would train both Dutch Reformed and Presbyterian clergymen. Students of the academy would have had to attend the college at Princeton for at least one year before receiving a degree. ${ }^{58}$

The Queen's College trustees narrowly defeated both proposals, even before Princeton had an opportunity to discuss them. As the idea of a merger with Princeton waned, the Synod of the Dutch Reformed Church showed its displeasure with the Queen's trustees over their negotiations by promising to withhold any financial support it may have secured for the college through subscriptions. When the restriction was 
lifted, the Synod raised the possibility of moving the college closer to the large Dutch population in northern New Jersey and New York, a prospect which favored the union of the college with that of the Professorship of Theology, then languishing with John Henry Livingston in the Dutch Reformed Church in New York. The trustees, cognizant that the Synod's plan would mean an end to the college in New Brunswick, voted against such a move and, with meager resources and diminishing prospects for the future, closed the college following the commencement exercises of $1795 .^{59}$

Though collegiate instruction ceased, the trustees continued the grammar school, which flourished in the early years of the nineteenth century, under the watchful eye of the Reverend Ira Condict. Condict, a graduate of the College of New Jersey (1784), had replaced Linn as President pro tempore in 1795 . It was also Condict, who from his pulpit in the Dutch Reformed Church in New Brunswick, engineered the move of the Theological Seminary from New York to its present home in New Brunswick. The Seminary grew vigorously under the stewardship of the venerable John Henry Livingston, who finally accepted the presidency of Queen's College in 1810.

Queen's College would revive in 1807, and shortly thereafter move into a new building designed by John McComb, architect of New York's city hall. Financial problems and alienation from the Synod would force suspension once again in 1816 . But by 1825 , the college would again reopen, this time on a permanent basis, known now as Rutgers College, named for Colonel Henry Rutgers, devoted member of the Dutch Reformed Church and benefactor of the college.

As Queen's College languished, the future of the College of New Jersey looked brighter, at least on the surface. The college, devastated by the Revolution, continued its slow recovery under the leadership of Samuel Stanhope Smith, who sought to provide continuity with the institution's past under John Witherspoon. ${ }^{60}$ But politics and religion were soon to play a significant role in the transformation of Princeton in the late 1790's.

As events in France deteriorated into anarchy, the faculty of the college became disillusioned with any prospects of a democratic revolution in Europe. Such events were magnified at home with the conduct of Citizen Gênét in the United States during 1793 and 1794. Washington's denunciation of Democratic societies following the Whiskey Rebellion and the contention surrounding the Jay Treaty with Great Britain both served to shatter the faculty's confidence in the nation's fate. The attack 
on Calvinistic religion in Tom Paine's Age of Reason shook the foundation of religious principles on which the college was founded. As partisan politics entered into the picture with the rise of Jeffersonian opposition, the Federalists of Nassau Hall took to the defense. In this political and moral climate, challenges to authority on the part of the students became increasingly suspect. Dissent and radicalism had suddenly found their way onto the college grounds at Princeton. ${ }^{61}$

The troubles for Samuel Stanhope Smith and his Princeton colleagues began in 1802 with the burning of Nassau Hall. The building was gutted and everything inside destroyed, including the library and scientific apparatus procured over many years by Witherspoon and the trustees. Students were suspected of arson. Smith claimed the event as "one effect of those irreligious and demoralizing principles which are tearing the bands of society asunder." 62 By 1807 the college had suffered widespread student rebellion that placed a predominantly Jeffersonian student population against a Federalist faculty, which agonized over the lack of Presbyterian discipline. Reacting to the rebellion, Ashbel Green, longtime trustee of the college, viewed President Smith as Princeton's biggest problem and organized an alumni revolt to force him from office in 1812. Green replaced Smith, and presided over the founding of the Princeton Theological Seminary to fulfill the college's earlier mission to supply trained Presbyterian ministers. Throughout his tenure as president, Green encouraged discipline and piety on the campus. In the process, the College of New Jersey turned back the clock by becoming more denominational and parochial, and demonstrating less faith in Witherspoon's Enlightenment alliance between science and religion. ${ }^{63}$

The colleges at Princeton and New Brunswick resembled each other in the early nineteenth century more than at any time in their history. While the College of New Jersey maintained larger enrollments, its influence in the nation's affairs diminished. Meanwhile, Rutgers College developed slowly into a respectable liberal arts college. The course of development for Princeton and Rutgers would run parallel until 1862, when their paths would cross once more. The issue this time was not union, but the land-grant status of New Jersey. The result would in effect redefine the mission and goal of each institution in the remaining years of the nineteenth century. 


\section{NOTES}

I. Queen's College Board of Trustees. Minutes and Enclosures, September 1793, Special Collections and University Archives, Rutgers University Libraries. See also Richard P. McCormick, Rutgers, A Bicentennial History (New Brunswick, NJ, 1966), pp. 21-22; William Henry Steele Demarest, A History of Rutgers College, 1766-1924 (New Brunswick, NJ, 1924), pp. 173-178.

2. The literature concerning the effects of the Great Awakening on religion and education in Colonial society is extensive. In conjunction with the founding of the College of New Jersey, I have relied on Howard Miller, The Revolutionary College: American Presbyterian Higher Education, 1707-1837 (New York, 1976), pp. 10-75, and Thomas Jefferson Wertenbaker, Princeton, 1746-1896 (Princeton, 1946), pp. 3-26.

3. Miller, The Revolutionary College, pp. 61-62.

4. The Log College was located in Neshaminy, Pennsylvania, where William Tennent, pastor of the Presbyterian church, instructed his four sons and other New Side revivalists in the classics and divinity. Several Log College alumni were instrumental in the founding of the College of New Jersey and served as trustees. See Francis L. Broderick, "Pulpit, Physics, and Politics: The Curriculum of the College of New Jersey, 1746-1794," William and Mary Quarterly, 3rd ser., 6 (January, 1949), pp. 4344; Wertenbaker, Princeton, pp. 11-13; Archibald Alexander, Biographical Sketches of the Founder and Principal Alumni of the Log College (Princeton, 1845); and Douglas Sloan, The Scottish Enlightenment and the American College Ideal (New York, 1971), pp. 36-72.

5. Alison's academy in New London, which subsequently moved to Newark, Delaware, was an ecclesiastical institution thoroughly controlled by the Synod of Philadelphia. However, the classical and literary course of study that Alison provided in his New London academy was probably as good as any available in the colonial colleges at the time. For a detailed examination of Alison's educational career, see Sloan, The Scottish Enlightenment, pp. 73-102.

6. Wertenbaker, Princeton, pp. 13-14.

7. Miller, The Revolutionary College, p. 65.

8. For a detailed documentary treatment of the expulsion of students at Yale, see Stephen Nissenbaum, ed. The Great Awakening at Yale (Belmont, CA, 1972).

9. John Frelinghuysen, the son of Theodorus Jacobus Frelinghuysen, was considered by many in the Dutch church to be a prophet of theological education. From his father's former parishes at Raritan, Millstone, and North Branch, Frelinghuysen, together with his wife, the former Dinah Van Berg, set apart a room within their home that served as an academy and theological seminary for the training of Dutch Reformed ministers, a forerunner to Queen's College and the New Brunswick Theological Seminary. Frelinghuysen served as a preceptor to Jacob Hardenbergh, the first President of Queen's College, who took over as pastor of the churches in Raritan in 1754, following the death of John Frelinghuysen at the young age of twenty-seven. Hardenbergh assumed an active role in the movement to establish a Dutch college, and married Dinah Van Berg Frelinghuysen in 1756. Edward T. Corwin, A Manual of the Reformed Church in America, 1628-1902 (New York, 1902); Demarest, A History of Rutgers College, pp. 23-30. For a detailed study of Theodorus Jacobus Frelinghuysen, see James Tanis, Dutch Calvanistic Pietism in the Middle Colonies (The Hague, Netherlands, 1967) especially pp. 42-93.

10. Demarest, $A$ History of Rutgers College, p. 27.

11. McCormick, Rutgers, A Bicentennial History, pp. 2-3. For a detailed discussion on the King's College controversy, see David C. Humphrey, From King's College to Columbia, 1746-1800 (New York, 1976), pp. 55-66. 
12. Quoted in Demarest, A History of Rutgers College, pp. 36-37.

13. Humphrey, From King's College to Columbia, pp. 63-65.

14. McCormick, Rutgers, A Bicentennial History, pp. 4-5; Demarest, $A$ History of Rutgers College, pp. 47-57.

15. George P. Schmidt, Princeton and Rutgers: The Two Colonial Colleges of New Jersey (Princeton, 1964), p. 10.

16. Charter of a College To Be Erected in New-Jersey By the Name of Queen's-College,... . (New York, 1770), p. 3; "Charters of the College of New Jersey, October 22, 1746 and September 14, 1748," in Wertenbaker, Princeton, pp. 396-404.

17. Schmidt, Princeton and Rutgers, pp. 9-10; Demarest, History of Rutgers College, pp. 7576.

18. The original charter of the College of New Jersey, granted by the acting royal governor of New Jersey, John Hamilton, in 1746, called for a governing body not to exceed twelve members. The second charter, signed by Governor Belcher in 1748, increased that number to twenty-three. Wertenbaker suggests that Hamilton opposed the charter but was "infirm, deaf, suffering from palsy," and dependent on a group of advisors to make important decisions, all of whom were supporters of the new college. See Princeton, pp. 21-22.

19. College of New Jersey [Samuel Blair, Jr.], An Account of the College of New-Jersey.... . (Woodbridge, NJ, 1764), pp. 11-12; quoted in Miller, The Revolutionary College, p. 84.

20. Wertenbaker, Princeton, p. 36.

21. Davies and Tennent traveled throughout England and Scotland, securing the confidence of the dissenting academies in the former, but greater financial assistance from evangelicals in the latter. Together they collected over $£ 3,200$ for the infant College of New Jersey; see Wertenbaker, Princeton, pp. 32-35 and Sloan, The Scottish Enlightenment, p. 70.

22. Aaron Burr, "Laws and Customs of New Jersey College," (November 9, 1748); quoted in Broderick, "Pulpit, Physics, and Politics," p. 49.

23. The description of the curriculum at Yale is based on that offered by Thomas Clap, president of Yale College, 1763-1766, and summarized in Broderick, "Pulpit, Physics, and Politics," p. 46.

24. Shippen's letters are quoted in John Maclean, History of the College of New Jersey (Philadelphia, 1877), I, pp. 132-133. See also Broderick, "Pulpit, Physics, and Politics," pp. 50-51, and Sloan, The Scottish Enlightenment, pp. 63-64.

25. Miller, The Revolutionary College, pp. 86-87.

26. Out of 1,781 degrees awarded in the colonial colleges between 1748-1768, Princeton conferred 313 , or $18 \%$ of the total. Harvard conferred $684(38 \%)$, Yale awarded 643 (36\%), and the other colleges combined awarded the remaining 141 (8\%). See James McLachlan, Princetonians, 1748-1768: A Biographical Dictionary (Princeton, NJ, 1976), p. xix.

27. Ibid., p. $\mathrm{xx}$.

28. Quoted in Broderick, "Pulpit, Physics, and Politics," pp. 55-56.

29. One must be cautious with these figures because career lines were not clearly defined in the eighteenth century. Many clergymen became teachers or cared for the sick; lawyers were often involved with government service, business, or some other occupation; see McLachlan, Princetonians, pp. xxi-xxii.

30. Miller, The Revolutionary College, p. 72.

31. McLachlan, Princetonians, p. xxii.

32. Richard A. Harrison, Princetonians, $1769-1775$ (Princeton, NJ, 1980), p. xvii.

33. Sloan, The Scottish Enlightenment, p. 111; Broderick, "Pulpit, Physics, and Politics," p. 61. 
34. John Witherspoon, "Address to the Inhabitants of Jamaica, and other West-India Islands, in behalf of the College of New Jersey," in The Works of the Reverend John Witherspoon (Philadelphia, 1800-1801), VIII, pp. 318-319; quoted in Sloan, The Scottish Enlightenment, p. 112.

35. Ashbel Green, The Life of the Revd John Witherspoon, ed. Henry Lyttleton Savage (Princeton, 1973), p. 132.

36. For detailed discussion of Witherspoon's "common sense" philosophy and his attacks on Hume's radical skepticism and Berkeley's idealism, see Miller, The Revolutionary College, pp. 163-166; Broderick, "Pulpit, Physics, and Politics," pp. 6263; Sloan, The Scottish Enlightenment, pp. 117-131; and Mark A. Knoll, Princeton and the Republic, 1768-1822: The Search for a Christian Enlightenment in the Era of Samuel Stanhope Smith (Princeton, 1989), pp. 36-47.

37. The Rittenhouse orrery was destroyed during the British and American occupations of Nassau Hall during the Revolution, and was not repaired for a quarter of a century; see Wertenbaker, Princeton, pp. 108-109.

38. Witherspoon, "Address to the Inhabitants of Jamaica," Works, VIII, pp. 318-319.

39. Between 1769 and 1775 , Princeton conferred 150 bachelor's degrees, $18 \%$ of all 830 degrees granted in America. Harvard graduated $37 \%$ and Yale 22\%; see Harrison, Princetonians, 1769-1775, pp. xix-xx.

40. Ibid., pp. xxvii-xxix.

41. Demarest, A History of Rutgers College, pp. 73-74.

42. The founding of a grammar school helped solidify support among the trustees for locating Queen's College in New Brunswick. In addition to three clergymen who served as college trustees, the founders of the grammar school included the Mayor of New Brunswick, a prominent physician, and an Anglican minister, all of whom looked upon the school as an important community institution as well as a preparatory school for Queen's College. On the founding and history of the grammar school, see Frank V. Sperduto, A History of Rutgers Preparatory School (Somerset, NJ, 1967), Pp. 3-15; and Demarest, $A$ History of Rutgers College, pp. 70-73.

43. The New York Journal or the General Advertiser (April 30, 1772), as quoted in Demarest, A History of Rutgers College, pp. 84-85.

44. Rules and Regulations for the Government of Queen's College in New-Jersey Enacted by a Board of Trustees of Said College, the 7th day of A ugust, 1787 (New Brunswick, NJ, 1788), p. 12; see also McCormick, Rutgers, A Bicentennial History, p. 20.

45. Queen's College Trustees to the Classis of Amsterdam, December 30, 1772, in Demarest, $A$ History of Rutgers College, pp. 94-96.

46. Quoted in McCormick, Rutgers, A Bicentennial History, p. 15.

47. Wertenbaker, Princeton, pp. 55-57; Harrison, Princetonians, pp. xxx-xxxi.

48. Transactions of the Athenian Society, 1776-1786, June 29 and November 20, 1776. Special Collections and University Archives, Rutgers University Libraries; also quoted in McCormick, Rutgers, A Bicentennial History, p. 16. On the acquisition of the Transactions and the history of the Athenian Society, see Mildred R. Woodward, "The Athenian Society of Queen's College," Journal of the Rutgers University Libraries, III, No. 1 (December, 1939), pp. 12-19.

49. The experience of the tutor and students of Queen's College during the Revolution is documented in The John Bogart Letters, 1776-1782 (New Brunswick, NJ, 1914), especially John Taylor to John Bogart, July 2, 1779, pp. 18-19. Also included are a number of letters written by Simeon DeWitt (Queen's, 1776), who served as General Washington's chief geographer.

50. Wertenbaker, Princeton, p. 63.

51. Theodore W. Wells, Hardenbergh: Leaves Out of Ancestral Tablets, From Colonial Days to the Present Era, (n.p., n.d.), p. 117. 
52. Maxine N. Laurie, "New Jersey and the Bicentennial: A Look at the Rutgers Connection," Douglass College Alumnae Bulletin, 62, No. 1 (Fall, 1987), pp. 1-5.

53. John Murrin, "Introduction," Princetonians, 1784-1790 (Princeton, NJ, 1991), p. xxviii.

54. Harrison, Princetonians, 1776-1783, pp.xxvi-xxvii; Murrin, Princetonians, 1784-1790, p. xxviii.

55. Princetonians, $1784-1790$, p. Iviii.

56. "The Rev. William Linn, D.D.," The Magazine of the Reformed Dutch Church, IV, No. 2 (May, 1829), pp. 33-35.

57. The statistics for the College of New Jersey are from Princetonians, 1776-1783 and Princetonians, 1784-1790; those for Queen's College are compiled from Catalogue of the Officers and Alumni of Rutgers College, 1776-1916 (Trenton, NJ, 1916), pp. 66-71 and Rutgers Alumni Biographical files (Classes of 1771-1794), Special Collections and University Archives, Rutgers University Libraries.

58. Queen's College Board of Trustees. Minutes and Enclosures, September 1793, Special Collections and University Archives, Rutgers University Libraries. Of particular interest in the trustees' records are "Observations upon the overture respecting an Union between College at Brunswick and that at Princeton," and the plan submitted by the Rev. John Bassett, September 28, 1792, both of which propose that Queen's College become a theological seminary.

59. Trustees minutes, August 13, 1794 (typescript); Demarest, History of Rutgers College, pp. 178-180; McCormick, Rutgers, A Bicentennial History, pp. 22-23.

60. On the Princeton career of Samuel Stanhope Smith, see Sloan, The Scottish Enlightenment, pp. 146-184; and especially Knoll, Princeton and the Republic, 1768-1822, which is centered on Smith at Princeton.

61. Knoll, Princeton and the Republic, pp. 135-144.

62. Stanhope Smith to Jedediah Morse, March 10, 1802, quoted in Sloan, The Scottish Enlightenment, p. 180.

63. Princetonians, 1784-1790, pp. Ivii-lviii. On the student revolts at Princeton, see especially Steven J. Novak, The Rights of Youth: American Colleges and Student Revolt, 1798-1815 (Cambridge, Massachusetts, 1977), pp. 21, 31-37, 115-123. 